\title{
EDITORIAL
}

\section{BESAR SETIAMU}

\author{
Audy Santoso \\ Great is Thy faithfulness, O God my Father \\ There is no shadow of turning with Thee \\ Thou changes not, Thy compassion's, they fail not \\ As Thou hast been, Thou forever will be \\ Great is Thy faithfulness \\ Great is Thy faithfulness \\ Morning by morning new mercies I see \\ All I have needed Thy hand hath provided \\ Great is Thy faithfulness, Lord, unto me
}

Puisi 'Great is Thy Faithfulness' dituliskan oleh Thomas O. Chisholm. Di dalam hidupnya Chisholm pernah ditahbiskan dan menjadi pelayan di gereja Methodist, namun hanya untuk setahun. Dia mengundurkan diri karena sakit-sakitan, kemudian dia melanjutkan hidupnya dengan bekerja menjual asuransi. Namun Tuhan berkehendak Chisholm hidup hingga mencapai usia yang cukup tua. Dia meninggal di tahun 1960 pada usia 94 tahun. Seumur hidupnya ada sekitar 1200 puisi yang dituliskan Chisholm. Great is Thy faithfulness, O God my Father. Seperti Chisholm, kita tidak memiliki pengetahuan akan apa yang mungkin terjadi pada hidup kita. Namun kita memiliki iman yang sama kepada Bapa di Sorga. Di tengah pandemi Covid-19 yang masih melanda dunia dan seakan tiada kepastian akan hari depan, lagu ini memberikan pengharapan dan sukacita. Siapakah Allah? Ia adalah Bapa yang memiliki kesetiaan yang besar. Sang Bapa tinggal di dalam terang mutlak yang tak terhampiri (1 Tim. 6:16), sehingga tidak ada bayang-bayang perubahan dalam diriNya.

Umat Tuhan di dalam sejarah pun dapat mengalami pergumulan, ada periode-periode dimana Tuhan diam bukan dalam rentang waktu yang singkat, melainkan sampai ratusan tahun. Setidaknya dua periode seperti 
demikian: pada saat Israel diperbudak di Mesir selama 400 tahun, dan pada saat masa inter-testamental yang juga 400 tahun Tuhan tidak mengirimkan nabi dan berfirman. Saat-saat demikian umat Tuhan diajar untuk berdoa. Jawaban doa Israel di Mesir dijawab dengan lahirnya seorang bayi bernama Musa. Namun jawaban doa ini membutuhkan waktu 80 tahun lagi hingga akhirnya Tuhan memanggil dan mengutus Musa di usia tersebut. Sama halnya dengan doa Zakharia yang dijawab, Yohanes pembaptis pun masih membutuhkan 30 tahun lagi hingga akhirnya dipakai oleh Tuhan menjadi nabi di padang belantara. Thou changest not, Thy compassion's they fail not. Tuhan akan bertindak di dalam waktuNya.

Morning by morning new mercies I see. Kalimat ini penting untuk mengimbangi masa-masa sulit yang dihadapi. Selalu ada kebaikan Tuhan yang baru. Kalimat ini mengingatkan akan ayat-ayat penghiburan di Ratapan 3:2223. 'Tak berkesudahan kasih setia Tuhan, tak habis-habisnya rahmatNya, selalu baru tiap pagi; besar kesetiaan-Mu!' Allah yang menyatakan sedalam-dalam dirinya karakter 'penyayang dan pengasih' (Kel. 34:6), pastilah kasih dan rahmat Tuhan pun akan dinyatakan. Great is thy faithfulness. Yang menarik di ayat 24 dalam Ratapan 3 dikatakan 'Tuhan adalah bagianku'. Frase ini mengingatkan akan peristiwa masuknya Israel ke tanah Perjanjian, dimana 12 suku masing-masing mendapat bagiannya. Namun suku Lewi tidak mendapat bagian, dan dikatakan Tuhan adalah pusaka mereka (Yos. 18:7). Penghayatan ini ketika ditarik kepada zaman Yeremia yang meratap atas hancurnya Yehuda, hancurnya Yerusalem, hancurnya bait suci membawa kepada satu pemahaman yang indah. Ketika semuanya habis, masihkah jiwa kita mengatakan 'Tuhan adalah bagianku'? Israel yang dibuang ke Babel diajak menghayati seperti suku Lewi hidupi, menghayati kecukupan hanya di dalam Tuhan saja.

Kebaikan Tuhan yang kita terima setiap hari sudah sepatutnya membawa kita kepada kehidupan bersyukur, termasuk di pada masa pandemi. Saat begitu sulit menimpa seluruh penduduk dunia, kebaikan tetap kita terima karena berasal dari tangan Allah yang memelihara. Pujian Yeremia di tengah-tengah ratapan menjadi satu pujian yang demikian meninggikan Tuhan. Tuhan bukan hanya bertakhta di Israel. Tuhan yang sejati juga bertakhta bersama umatNya yang terbuang. Suatu pujian memiliki karakter kekekalan yang melintasi zaman ke zaman. Pujian yang muncul puluhan, ratusan, bahkan ribuan tahun yang lampau memiliki keberlangsungan yang everlasting ketika dinyanyikan dari zaman ke zaman. Allah yang ditinggikan diatas pujian menyatakan suatu fakta bahwa dia adalah Allah yang bertakhta secara kekal dari zaman ke zaman untuk selamanya. 
Dalam edisi jurnal Verbum Christi bulan Oktober 2020 ini, terdapat 5 artikel pilihan. Artikel pertama dituliskan oleh Audy Santoso dengan judul The Revolution of Worship. Di artikel ini Santoso menelusuri perkembangan revolusioner dalam ibadah yang dikerjakan oleh Daud dan Yesus sang anak Daud. Artikel ini penting mengingat pujian merupakan hal yang biasa di dalam ibadah Kristen, namun dimasukkannya elemen pujian ini ternyata memiliki kaitan erat dengan sejarah keselamatan.

Artikel kedua yang juga mengenai pujian ditulis oleh Maria Stefany dengan judul Teologi Salib dalam St. John Passion: Kristus Dimuliakan Melalui PenderitaanNya. Stefany mengajak pembaca menghayati salah satu karya terindah dari Johann Sebastian Bach, St. John's Passion. Penderitaan yang dialami oleh Kristus bukanlah suatu sengsara yang nihil makna, melainkan justru dilihat sebagai kemuliaan di dalam perspektif Injil Yohanes. Pemikiran ini menjadi suatu ingatan yang menyejukkan melihat penderitaan pun dapat bersifat instrumental untuk mencapai telos yang lebih besar.

Artikel ketiga ditulis oleh Sutjipto Subeno yang berjudul Sumbangsih Pemikiran Etika John Frame di dalam Mengisi Pengharapan Masyarakat 5.0 di Era Revolusi Industri 4.0. Subeno melihat perkembangan industri terkini yang mengubah tatanan masyarakat dapat membawa dampak yang berbahaya jika tidak ada standar etika. Karenanya, Subeno melihat pemikiran etika John Frame melalui tiga perspektifnya dapat menjadi sumbangsih kekristenan di tengah keacuhan masyarakat yang berteknologi. Di tengah keoptimisan naif manusia dengan majunya teknologi, pandemi menjadi pengingat yang baik bagi manusia untuk tidak abai maupun acuh akan Allah yang merupakan standard moral yang sejati.

Masih terkait dengan tema etika, artikel keempat yang ditulis oleh Yuki Fran Siska dan Jadi S. Lima berjudul Relevansi Pandangan William Gouge Mengenai Tanggung Jawab Orang Tua dan Anak Terkait Disiplin dalam Keluarga. Siska dan Lima menyoroti fakta ekstrem disiplin antara kekerasan dan pengabaian. Disini para penulis melihat pandangan William Gouge, seorang Puritan akan pentingnya peran orang tua dan anak yang resiprokal di dalam keluarga kristen. Sebagaimana etika orang Puritan, acuan bagi Gouge di dalam mengembangkan konsep disiplinnya bersumber dari alkitab yang membentuk hidup keluarga, baik orang tua maupun anak-anak.

Artikel terakhir ditulis oleh Doni Herwanto Harianja dan Antonius S. Un dengan judul Rethinking Trinitarian Mission: Perspectives of Lesslie Newbigin and Johan Herman Bavinck. Allah yang mana setiap manusia dicipta adalah Allah Tritunggal. Relasionalitas di dalam Allah sejati inilah yang seharusnya mendorong seseorang untuk bermisi. Harianja melihat adanya kesamaan pentingnya pemahaman ketritunggalan Allah di dalam teologi misi pada 
pemikiran Leslie Newbigin dan Johan Herman Bavinck. Berlandaskan keterkaitan ini, maka Harianja melihat pentingnya keseimbangan antara penginjilan dan keadilan sosial di dalam pelayanan misi. Di saat pandemi ini terjadi, gereja dapat menjalankan misi Tuhan dengan meringankan beban ekonomi yang menghimpit dunia ekonomi yang memberikan tekanan bagi banyak keluarga. Misi yang komprehensif ini memiliki pengharapan bahwa setiap harinya lebih banyak orang yang dapat mengatakan 'Great is Thy faithfulness, Lord, unto me'. Selamat membaca! 